\title{
Gallbladder Metastasis from Renal Cell Carcinoma
}

\author{
Takashi Kawahara $^{a}$ Hisashi Ohshiro $^{b}$ Zenkichi Sekiguchia

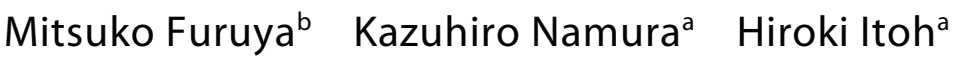 \\ Futoshi Sano $^{\text {a Kaoru Kawaji }}{ }^{\mathrm{a}}$ Narihiko Hayashi ${ }^{\mathrm{a}}$ \\ Kazuhide Makiyama ${ }^{a}$ Noboru Nakaigawa ${ }^{a}$ \\ Takehiko Ogawa $^{a}$ Hiroji Uemura ${ }^{a}$ Masahiro Yao \\ Yoshinobu Kubota ${ }^{\mathrm{a}}$ \\ aDepartment of Urology, Yokohama City University Graduate School of Medicine, \\ and ${ }^{b}$ Department of Pathology, Yokohama City University Hospital, Yokohama, \\ Japan
}

\section{Key Words}

Gallbladder metastasis $\cdot$ Renal cell carcinoma $\cdot$ Sunitinib

\begin{abstract}
A 73-year-old female was operated with radical nephrectomy and cholecystectomy for renal cell carcinoma and suspected gallstones after 9 courses of sunitinib treatment. Gallbladder specimen showed gallbladder metastasis originating from the renal cell carcinoma. Gallbladder metastasis from renal cell carcinoma is rare. Here, we discuss a case of gallbladder metastasis from renal cell carcinoma.
\end{abstract}

\section{Introduction}

Renal cell carcinoma is a tumor that often spreads to organs with a large blood flow volume, such as the lungs, the liver, and bones. Reports of clinical cases of metastasis to the gallbladder are rare, and in many of these reported cases, the metastasis is found by chance during autopsy. We treated a case of gallbladder metastasis of renal cell carcinoma and, in this study, we report this case in addition to several bibliographical considerations.

\section{Case Report}

The patient was a 73-year-old female with a chief complaint of gross hematuria. She had no past history in particular. 


\begin{tabular}{c|l|l|l}
$\begin{array}{c}\text { Case Reports in } \\
\text { Oncology }\end{array}$ & $\begin{array}{l}\text { Case Rep Oncol 2010;3:30-34 } \\
\text { Dol: } 10.1159 / 000279308\end{array}$ & & $\begin{array}{l}\text { Published online: January 29, 2010 S. Karger AG, Basel } \\
\text { ISSN 1662-6575 } \\
\text { www.karger.com/cro }\end{array}$ \\
\hline
\end{tabular}

\section{Current Medical History}

In May 2008, the patient noticed blood in her urine and visited our department. A computed tomography (CT) showed renal cell carcinoma with multiple lung metastasis and invasion to the inferior vena cava, resulting in a diagnosis of clinical stage T3bNOM1. She received 9 courses of sunitinib treatment: 1 course of $50 \mathrm{mg}$ /body from July 2008 to August 2008, 1 course of $37.5 \mathrm{mg} / \mathrm{body}$ from August 2008 to September 2008, 7 courses of 25 mg/body from September 2008 to August 2009. Considering the reduction of tumor thrombosis and good control of lung metastases, she was admitted to our department for surgery.

\section{Laboratory Data at the Time of Admission}

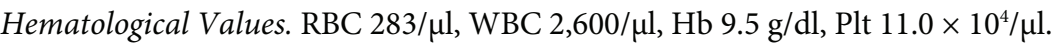

Biochemistry. AST 75 IU/l, ALT 20 IU/l, ALP 263 IU/l, LDH 475 IU/l, BUN 11 mg/dl, Cre 0.93 $\mathrm{mg} / \mathrm{dl}$, CRP $0.81 \mathrm{~g} / \mathrm{dl}$.

Urinary Analysis. Within normal limits.

\section{${ }^{18}$ F-Fluorodeoxyglucose Positron Emission Tomography (PET)/CT Findings}

${ }^{18} \mathrm{~F}$-fluorodeoxyglucose (FDG) accumulations with a low level of accumulation in the center were observed in the upper pole of the right kidney. These accumulations extended from the renal hilus toward the inferior vena cava and the $S U V_{\max }$ was 5.8. Multiple negative nodules were observed on both sides, and these were believed to be lung metastases of the renal carcinoma.

\section{Specimens Removed}

The removed kidney was $827 \mathrm{~g}$ in weight and $110 \times 100 \times 90 \mathrm{~mm}$ in size. A yellowish white to winecolored tumor was observed along with a clear cell renal carcinoma $4 \times 3 \mathrm{~mm}$ in size within the kidney on the same side. The removed gallbladder was $105 \times 60 \times 20 \mathrm{~mm}$ in size, and a polypoid nodule $10 \times 8$ $\mathrm{mm}$ in size was observed in the neck of the gallbladder ( $\underline{\text { fig. } 1 \text { ). }}$.

\section{Histopathological Findings}

The renal carcinoma within the removed kidney was of a clear cell type, and invasion into the right vein was observed (fig. 2). With regard to the polypoid nodule in the gallbladder, an alveolar composed of clear tumor cells accompanied by abundant angiogenesis was observed. The histological type coincides with that of the removed kidney (i.e., clear cell carcinoma) (fig. 3 ).

\section{Discussion}

Distant metastases of renal cell carcinoma discovered during autopsy are mostly found in the lungs, the liver, and bones. Metastasis to the gallbladder is very rare and is found in only $0.4-0.6 \%$ of specimens $[1,2]$. Besides, malignant melanomas are the most common cause of metastatic tumors of the gallbladder, and metastases of lung, renal, pancreatic, and colorectal cancers have been reported $[1,3]$. However, the number of clinical cases reported so far does not exceed 20. Furthermore, there have only been 10 cases, including this one, in which the metastasis did not involve any organs other than the gallbladder [411]. In all cases, the histological type was clear cell carcinoma.

With respect to the mechanisms of secondary tumors of the gallbladder, Willis [1] grouped the processes of metastasis to the gallbladder into 2 categories including direct invasion of the tumor and invasion of the tumor into the blood vessel capillaries, saying that the latter process is comparatively rare. The gallbladder metastasis occurred 


\begin{tabular}{c|l|l|l}
$\begin{array}{c}\text { Case Reports in } \\
\text { Oncology }\end{array}$ & $\begin{array}{l}\text { Case Rep Oncol 2010;3:30-34 } \\
\text { Dol: } 10.1159 / 000279308\end{array}$ & & $\begin{array}{l}\odot \text { 2010 S. Karger AG, Basel } \\
\text { ISSN 1662-6575 } \\
\text { www.karger.com/cro }\end{array}$ \\
\hline
\end{tabular}

simultaneously in half of the cases and recurred metachronously in half of the cases. Another characteristic of these cases is the discrepancy of 19 months to 27 years for the time between the resection of the primary tumor and the reappearance of the tumor cells.

According to Takebayashi et al. [12], the features to be noted in preoperative diagnoses of metastatic gallbladder carcinoma with the use of diagnostic imaging include: (1) the appearance of the carcinoma on CT images and in angiography as a polypoid lesion representing significant tumor staining; and (2) the appearance of an echo-bright area on the surface of the tumor indicating a submucosal tumor on ultrasound images. However, they reported that it is extremely difficult to distinguish cases of primary and metastatic gallbladder carcinoma. In our present case, PET/CT scans were performed before surgery. There having been no reports on PET/CT scans used to detect gallbladder metastasis of renal cell carcinoma, this report is the first such report. The PET/CT images indicated a tumor mass within the gallbladder wall, but the FDG images were not very clear.

In cases of renal carcinoma in which a gallbladder mass is observed simultaneously or metachronously, although it is difficult to obtain a preoperative diagnosis of gallbladder metastasis, the possibility of gallbladder metastasis should be taken into account.

Fig. 1. Gallbladder specimen.

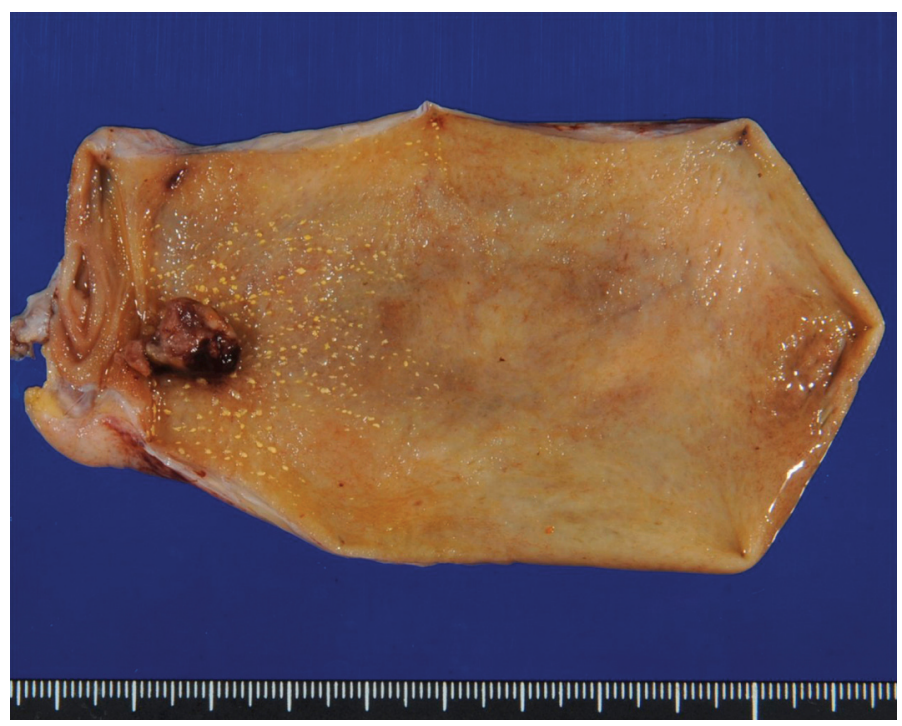




\begin{tabular}{c|l|l|l}
$\begin{array}{c}\text { Case Reports in } \\
\text { Oncology }\end{array}$ & $\begin{array}{l}\text { Case Rep Oncol 2010;3:30-34 } \\
\text { D0I: 10.1159/000279308 }\end{array}$ & $\begin{array}{l}\text { Published online: January 29, 2010 } \\
\text { ISSN 1662-6575 AG, Basel } \\
\text { www.karger.com/cro }\end{array}$ \\
\hline
\end{tabular}

Fig. 2. Renal. Hematoxilin-Eosin (HE) staining $(\times 400)$.

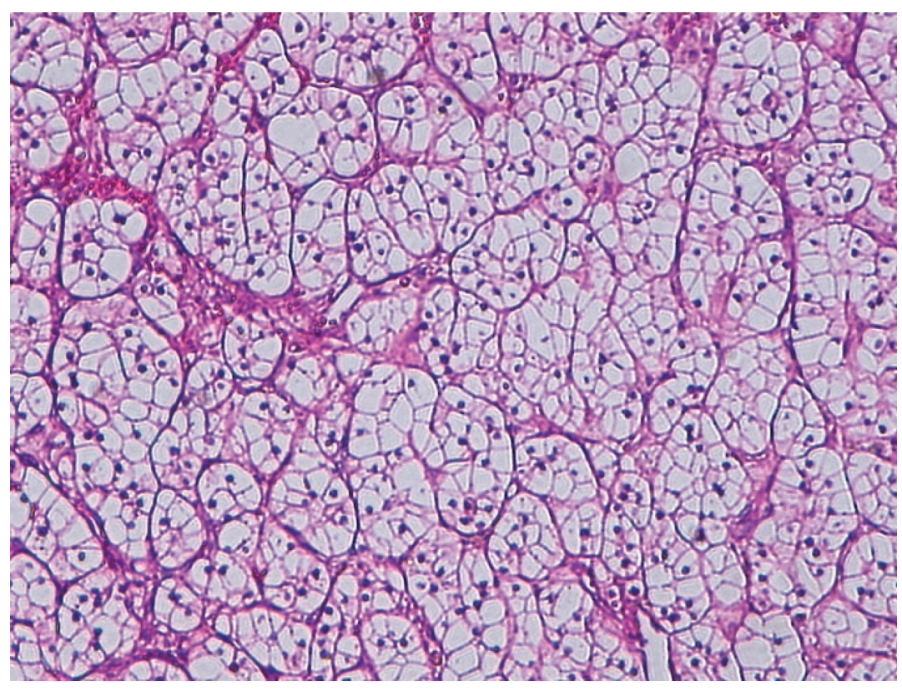

Fig. 3. Gallbladder. Hematoxilin-Eosin (HE) staining $(\times 400)$.

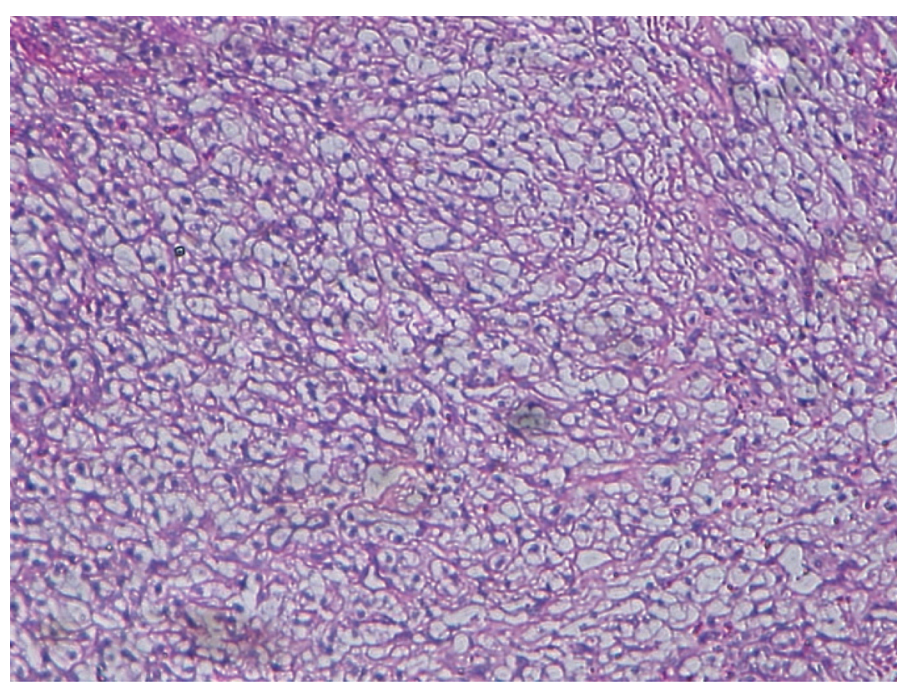




\section{References}

1 Willis RA: The Spread of Tumors in the Human Body. 2nd ed. London, Butterworth, 1952, pp 218-219.

2 Bennington JL, Kradjian R: Renal Carcinoma. Philadelphia, WB Saunders, 1967, pp 34-35.

-3 Satoh H, Iyama A, Hidaka K, et al: Metastatic carcinoma of the gallbladder from renal cancer presenting as intraluminal polypoid mass. Dig Dis Sci 1991;36:520523.

-4 Botting AJ, Harrison EG, Black BM: Metastatic hypernephroma masquerading as polypoid tumor of the gallbladder and review of metastatic tumors of the gallbladder. Proc Staff Meet Mayo Clin 1963;38:225-232.

-5 Golby S, Gerard PS, Frank RG: Metastatic hypernephroma masquerading as acute cholecystitis. Clin Imaging 1991;15:293-295.

-6 Nagler J, Mcsherry CK, Miskovitz P: Asymptomatic metachronous metastatic renal cell carcinoma to the gallbladder. Dig Dis Sci 1984;39:2476-2479.

-7 King DHC, Centeno AS, Saldivar VA, et al: Renal cell carcinoma metastatic to the gallbladder or prostate: two care reports. Urology 1995;46:722-725.

-8 Lombardo FP, Hertfold DE, Shanahan EM, et al: Color Doppler ultrasonographic evaluation of renal cell carcinoma metastasis to the gallbladder. J Ultrasound Med $1996 ; 15: 725-728$

9 Aoki T, Inoue K, Tsuchida A, et al: Gallbladder metastasis of renal cell carcinoma: Report of two cases. Surg Today 2002;32:89092.

10 Finkelstein LH, Coffman LM: Acute cholecystitis or metastatic renal cell carcinoma? A diagnostic dilemma. JAOA 1996;96:314-315.

11 Miyagi T, Kitagawa Y, Katsumi T, et al: A case of metastatic gallbladder tumor from unilateral renal cell carcinoma. Rinsyo Hinyokika 2003;57:257-259.

12 Takebayashi M, Toyota N, Noaka K, et al: Two cases of gallbladder metastasis from renal cell carcinoma. J of Japan Surg Association 2006;67:2717-2722. 